Note

\section{Substrate Specificity of Cysteine Proteinase from Sprouting Potato Tubers}

\author{
Nobuo Kitamura, ${ }^{*}$ Akihiro Okitani** \\ and Yoshiharu MARUYAMA
}

\author{
Department of Agricultural Chemistry, \\ The University of Tokyo, Bunkyo-ku, Tokyo 113, Japan \\ *Institute of Physical and Chemical Research, \\ Honkomagome 2-28-8, Bunkyo-ku, Tokyo 113, Japan \\ **Department of Food Science and Technology, \\ Nippon Veterinary and Zootechnical College, \\ Musashino-shi, Tokyo 180, Japan
}

Received September 29, 1988

We previously reported the identification and the purification of the cysteine proteinase from potato tubers. ${ }^{1,2)}$

This enzyme, induced in potato tubers during sprouting, was one single polypeptide chain with a molecular weight of 28000 , and having the properties of a weakly and strong endopeptidic proteinase. ${ }^{2)}$

In addition to those properties, this enzyme has hydrolyzed BANA $(\alpha-N$-benzoyl-D,L-arginine $\beta$-naphthylamide) and was very sensitive to divalent cations, especially $\mathrm{Zn}^{2+}$, and to several inhibitors from microbes such as leupeptin, antipain, and E64. ${ }^{2)}$ These properties are coincident with those of the cysteine proteinases previously reported. ${ }^{8)}$

We have reported here the substrate specificity of this enzyme towards synthetic substrate compounds, especially some arginine-containing peptide derivatives, to compare with other cysteine proteinases.

The estimation of activities of this enzyme using $\beta$ naphthylamide derivatives as substrate was done as reported previously. ${ }^{2)}$

Amidase activity of the enzyme was measured by the release of ammonium from the hydrolysis of BAA $(\alpha-N-$ benzoyl-L-arginine-amide) after incubating with this enzyme at $37^{\circ} \mathrm{C}$ for $60 \mathrm{~min}$. In this assay, the reaction mixture was $600 \mu \mathrm{l}$ of $1 \mathrm{~mm}$ BAA $/ 2 \mathrm{~mm}$ EDTA solution, $300 \mu$ of A buffer (25 mM citrate/ $\mathrm{NaOH}$ buffer, $\mathrm{pH} 6.0$ ) containing the enzyme, and $300 \mu \mathrm{l}$ of B buffer $(0.4 \mathrm{M}$ citrate $/ \mathrm{NaOH} / 8 \mathrm{~mm}$ dithiothreitol buffer, $\mathrm{pH} 6.0$ ). Conways' method was used to measure ammonium using the phenol-nitroprusside coloring reaction. ${ }^{3.41}$

The fluorescent substrates, $\alpha-N-\mathrm{Bz}-\mathrm{L}-\mathrm{Arg}-\mathrm{MCA}(\alpha-N$ benzoyl-L-arginine-7-amide-4 methyl-coumarin), Boc-LGlu-L-Arg-L-Arg-MCA ( $t$-butyloxycarbonyl-L-glutamyl-
L-arginine-L-arginine-7-amide-4 methylcoumarin), $N$ CBZ-L-Phe-L-Arg-MCA ( $N$-carbobenzoxy-L-phenylalanylL-arginine-7-amide-4 methyl-coumarin), and L-Glu-L-LysL-Lys-MCA ( $t$-butyloxycarbonyl-L-glutamyl-L-lysine-L-lysine-7 amide-4 methylcoumarin) were used in the following method. The assays of this enzyme activity using above substrates were started by the incubation of the reaction mixtures at $37^{\circ} \mathrm{C}$ for a suitable period, followed by the addition of $30 \%$ acetate to stop the reaction. The activity was measured by fuorescent intensity at $460 \mathrm{~nm}$ in emission and $370 \mathrm{~nm}$ in excitation.

The reaction mixtures were $800 \mu 1$ of $1 \mathrm{~mm}$ each substrate solution diluted by $2 \mathrm{~mm}$ EDTA-containing distilled water from $5 \mathrm{~mm}$ stock substrates in DMSO (dimethylsulfoxide), $200 \mu$ of $\mathrm{A}$ buffer containing the enzyme protein, $200 \mu \mathrm{l}$ of $6.2 \%$ Brij 35, and $400 \mu \mathrm{l}$ of B buffer. Reaction times of these assays were $10 \mathrm{~min}$ for $N-\mathrm{CBZ}=\mathrm{L}-\mathrm{Phe}-\mathrm{L}-$ Arg-MCA, $15 \mathrm{~min}$ for $\alpha-N$-Bz-L-Arg-MCA, and $30 \mathrm{~min}$ for Boc-L-Glu-L-Lys-L-Lys-MCA.

The hydrolysis of BAPA ( $\alpha-N$-benzoyl-arginine- $p$-nitroanilide) was monitored by measuring $p$-nitroaniline as reported previously. ${ }^{1)}$

The hydrolysis of BAEE $(\alpha-N$-benzoyl-arginineethylester), $N$-CBZ-Gly-L-Phe ( $N$-carbobenzoxy-glycyl-Lphenylalanine), and $N$-CBZ-L-Lys- $p$ nitrophenylester ( $N$ carbobenzoxy-L-lysine- $p$-nitrophenylester) were analyzed as follows. Reaction mixtures in these assays contained $200 \mu$ of each $1 \mathrm{~mm}$ substrate solution prepared from $5 \mathrm{~mm}$ stock substrates dissolved in DMSO, $100 \mu 1$ of A buffer containing the enzyme, and $100 \mu \mathrm{l}$ of $\mathrm{B}$ buffer. After those mixtures were incubated for $60 \mathrm{~min}$ at $37^{\circ} \mathrm{C}$, the hydrolysis of both BAEE and N-CBZ-L-Lys-p-nitrophenylester was measured by the increase of absorption at $253 \mathrm{~nm}$ and

Table I. SUBSTRATE SPECIFICITY FOR SYNTHETIC COMPOUNDS

\begin{tabular}{llr}
\hline $\begin{array}{c}\text { Substrate } \\
(0.5 \mathrm{mM})\end{array}$ & \multicolumn{2}{c}{$\begin{array}{c}\text { Activity }^{b} \\
(\mu \mathrm{mol} / \mathrm{min} / \mathrm{mg})\end{array}$} \\
\hline L-Arg- $\beta$ NA & $($ ArgNA $)$ & n.d. \\
L-Arg-L-Arg- $\beta$ NA & & 1.16 \\
$\alpha-N$-Bz-D,L-Arg- $\beta$ NA & (BANA) & 4.40 \\
$\alpha-N$-Bz-D,L-Arg- $p$ NA & (BAPA) & 0.14 \\
$\alpha-N$-Bz-L-Arg-ethylester & (BAEE) & n.d. \\
$\alpha-N$-Bz-L-Arg-amide & & 0.06 \\
L-Lys- $\beta$ NA & (LNA) & n.d. \\
$N$-CBZ-Gly-L-Phe & & n.d. \\
$N$-CBZ-L-Lys $p$-nitrophenylester & & n.d. \\
\hline
\end{tabular}

a Arg, arginine; Lys, lysine; Gly, glycine; Phe, phenylalanine; $\beta \mathrm{NA}, \beta$-naphthylamide; $\mathrm{CBZ}$, carbobenzoxy; $p$ NA, $p$-nitroanilide.

${ }^{b}$ means of three measurements. n.d., not detected. 
Table II. Kinetic PARAmeters For SYNTHETIC SUBSTRATES

\begin{tabular}{|c|c|c|c|}
\hline Substrates $^{a}$ & $\begin{array}{l}K m^{b} \\
(\mathrm{mM})\end{array}$ & $\begin{array}{c}k_{\text {cat }}^{c} \\
\left(\min ^{-1}\right)\end{array}$ & $\begin{array}{c}k_{\mathrm{cat}} / \mathrm{Km}^{d} \\
\left(10^{3} \mathrm{M}^{-1} \mathrm{~min}^{-1}\right)\end{array}$ \\
\hline $\begin{array}{l}\alpha-N-\mathrm{Bz}-\mathrm{D}, \mathrm{L}-\mathrm{Arg}-\beta \mathrm{NA} \\
\quad(\mathrm{BANA})\end{array}$ & 0.24 & 0.39 & 1.66 \\
\hline L-Arg-L-Arg- $\alpha$ NA & 2.50 & 0.01 & 0.04 \\
\hline$\alpha-N-\mathrm{Bz}-\mathrm{D}, \mathrm{L}-\mathrm{Arg}-p \mathrm{NA}$ & 2.85 & 0.02 & 0.01 \\
\hline$\alpha-N-\mathrm{Bz}-\mathrm{L}-\mathrm{Arg}-\mathrm{MCA}$ & 0.11 & 7.10 & 64.55 \\
\hline $\begin{array}{c}\text { Boc-L-Glu-L-Arg- } \\
\text { L-Arg-MCA }\end{array}$ & 0.04 & 5.26 & 131.50 \\
\hline $\begin{array}{l}N \text {-CBZ-L-Phe- } \\
\text { L-Arg-MCA }\end{array}$ & 0.04 & 400.00 & 10000.00 \\
\hline $\begin{array}{c}\text { Boc-L-Glu-L-Lys- } \\
\text { L-Lys-MCA }\end{array}$ & 1.26 & 5.00 & 3.97 \\
\hline
\end{tabular}

a Bz, benzoyl; MCA, 7-amide 4-methyl cumarin; Boc, $t$-butyloxycarbonyl; Glu, Glutamyl.

$b, c, d$ means of three measurements.

$340 \mathrm{~nm}$, respectively, and the decrease of absorption at $232 \mathrm{~nm}$ was used to estimate the hydrolysis of $N$-CBZ-GlyL-Phe.

The enzyme samples used throughout all assays were the same fraction as those finally purified in our previous report. $^{2)}$

Table I shows the specificity of this enzyme towards several kinds of synthetic substrates.

Apparently, the arginine derivatives depicted in this table were fairly hydrolyzed, especially $\alpha$-naphthylamide derivatives such as BANA. Table I also shows that this enzyme seems to have neither aminopeptidase nor carboxypeptidase activities judging from the results on Lys$\beta \mathrm{Na}, \operatorname{Arg}-\beta \mathrm{Na}$, and $N-\mathrm{CBZ}$ derivatives.

On the other hand, the action pattern towards BAA, BAPA, BANA, and BAEE suggest that this enzyme has amidase activity but not an esterase one.

Since the activity of this enzyme of $\mathrm{L}-\mathrm{Arg}-\mathrm{Arg}-\beta \mathrm{Na}$ was one-third as that on BANA, it seems that the aromatic structure in $\mathrm{P}_{2}$ position of substrates (in the terminology of Schechter and Berger) is important for the enzyme activity. ${ }^{101}$

Table II shows some kinetic constants of this enzyme using arginine derivatives as substrates, calculated by the method of Wilkinson. ${ }^{5)}$

The values of $k_{\text {cat }}$ on BANA, BAPA, and especially MCA derivatives suggest that $\mathrm{C}$-terminal compounds in those substrates, the $\mathbf{P}_{1}^{\prime}$ position, affect the ability of this enzyme catalysis.

The results on MCA derivatives show these compounds to be very effective substrates for this enzyme. Of all substrates listed in this table, N-CBZ-L-Phe-L-Arg-MCA has the highest susceptibility to this enzyme. The low $\mathrm{Km}$ of this substrate suggests the high affinity effect of arginine to the $S_{1}$ site on this enzyme compared to lysine and other amino acids. As seen in Table II, both the effects of $k_{\text {cat }}$ and $\mathrm{Km}$ give this compound highly sensitive properties as the substrate to the enzyme.

The evidence that this enzyme has high activity on $N$ CBZ-L-Phe-L-Arg-MCA, which had been prepared as a suitable compound for cathepsin B and moreover found to be also highly sensitive to cathepsin L, suggests this enzyme to be classified as an end type cysteine protease like lysozomal enzymes. ${ }^{6}$

Recently, cysteine proteases, classified as similar to cathepsin B, L, and $\mathrm{H}$ in animal lysozome, have been found in a wide variety of species, from bacteria to plants and animals. ${ }^{7 \sim 9)}$

This enzyme also seemingly belongs to the family of such enzymes judging from the properties depicted here. Those facts may present interesting meterials for research and discussion of the evolution of cysteine proteinases.

\section{References}

1) N. Kitamura and Y. Maruyama, Agric. Biol. Chem., 49, 1951 (1985).

2) N. Kitamura and Y. Maruyama, Agric. Biol. Chem., 50, 381 (1986).

3) H. Tauber, J. Biol. Chem., 188, 125 (1951).

4) A. L. Chaney and E. P. Marbach, Clinic. Chem., 8, 2 (1962).

5) G. L. Wilkinson, Biochem. J., 80, 324 (1961).

6) A. J. Barrett, Biochem. J., 187, 909 (1980).

7) K. Abe, H. Kondo and S. Arai., Agric. Biol. Chem., 51, 1509 (1987).

8) C. A. Ryan and M. Walker-Simons, "The Biochemistry of Plants," Vol. 6, Academic Press Inc., New York, 1981, p. 321.

9) A. J. Barrett," Proteinase in Mammalian Cells and Tissues," Elsevier/North Holland Biomedical Press, Amsterdam, 1977, p. 181

10) I. Schechter and A. Berger, Biochem. Biochem. Res. Commun., 27, 2 (1967). 